\title{
32. SULFUR ISOTOPE STUDIES OF EVAPORITES AND SHALES FROM SITES 225, 227, AND 228 IN THE RED SEA
}

\author{
W. C. Shanks and J. L. Bischoff, Department of Geological Sciences, \\ University of Southern California, Los Angeles, California \\ and \\ I. R. Kaplan, Department of Geology and Institute of Geophysics and Planetary Physics, \\ University of California, Los Angeles, California
}

\section{INTRODUCTION}

Sulfur isotope composition can provide evidence concerning genesis of sulfur-bearing minerals (Jensen, 1967; Ault and Kulp, 1960). Sulfur isotope analyses were therefore carried out on evaporites from Sites 225, 227, and 228 to shed light on possible relationships between base metal sulfides of the Atlantis II Deep (Bischoff, 1969: Hackett and Bischoff, 1973) and adjacent sedimentary sulfur minerals.

The two most abundant isotopes of sulfur, $\mathrm{S}^{34}$ and $\mathrm{S}^{32}$, are fractionated in natural processes, and maximum fractionation occurs when sulfate sulfur is reduced to sulfide. The reduction is kinetically slow and is usually mediated by bacteria. Kaplan et al. (1963) have shown that reduction of sulfate by bacteria in marine sediments produces sulfides which are enriched in $\mathrm{S}^{32}$ and have a relatively large range of $\delta \mathrm{S}^{34}$ values, often extending to values as low as -30 or $-40 \%$. Sulfides associated with magmatic-type hydrothermal deposits, which may represent mantle derived sulfur, have a small range of $\delta \mathrm{S}^{34}$ averaging near $0 \%$ (Jensen, 1967).

Kaplan et al. (1969) and Hartman and Nielsen (1966) have determined that sulfur isotope composition of the base metal sulfides in the Atlantis II Deep follows neither of the above patterns, but displays a small range of +3.1 to +9.8 , averaging $+5.7 \%$. This isotopic composition is significant because it is analogous to the composition of many ancient stratiform and stratibound sulfide deposits (Stanton, 1972; Sangster, 1968). These values cannot be easily explained because the only available sources of large quantities of sulfur are seawater or evaporite deposits. Sulfate reduction by bacteria should produce sulfides of negative sulfur isotopic composition, and inorganic reduction would require high temperature (Kajiwara, 1971). Kaplan et al. (1969) concluded that the most likely source of sulfur is the thick section of Tertiary evaporites to the south of the Atlantis II Deep. They suggested that both metals and sulfides, which were obtained by reaction of $\mathrm{CaSO}_{4}$ or sulfate-rich brine with organic matter in shales are introduced into the Atlantis II Deep with the hot brine.

The present study of anhydrite and sulfides from Sites 225,227 , and 228 (Figure 1) is an attempt to clarify the source and the mode of introduction of sulfur into the Red Sea deposits. Sites 225 and 227 are located in the axial valley of the Red Sea near but not in the hot brine area. Site 228 is on the western flank of the axial valley approximately 150 miles south of the Atlantis II Deep.

\section{METHODS}

\section{Sulfates}

Samples 228-39-1-50 and 228-39-1-110 (Table 1) were leached with cold deionized water in an attempt to determine the sulfur isotope composition of originally interstitial sulfates which precipitated during storage and desiccation.

Anhydrite samples were digested in hot $6 \mathrm{~N} \mathrm{HCL}$, and sulfate sulfur was then quantitatively precipitated as barium sulfate (Table 1). After digestion a small insoluble residue remained which contained detrital material and metal sulfides. In one case, Sample 227-44-1-43, sulfur isotopes were determined on the sulfide material of the residue.

\section{Metal Sulfides}

Sulfate was removed from shale, anhydrite, or bromoform concentrates before sulfide dissolution by successive leaches with hot $6 \mathrm{~N} \mathrm{HCl}$. Metal sulfides were then oxidized in boiling aqua regia-bromine solution and precipitated as barium sulfate.

Duplicates of barium sulfate precipitates, from both sulfate and sulfide samples, were reduced to barium sulfide with graphite at $1150^{\circ} \mathrm{C}$. The sulfide was partially cooled under nitrogen and then precipitated as $\mathrm{Ag}_{2} \mathrm{~S}$. Sulfur dioxide gas was produced by oxidation of the silver sulfide with cuprous oxide at $850^{\circ} \mathrm{C}$ and used for $\mathrm{S}^{34} / \mathrm{S}^{32}$ measurement.

Sulfur isotope ratios were analyzed on the sulfur dioxide at UCLA on the dual collection mass spectrometer manufactured by the Nuclide Corporation. Values are reported in the conventional manner as $\delta \mathrm{S}^{34}$ relative to the troilite phase of the Canon Diablo meteorite.

\section{RESULTS}

There do not appear to be any significant variations among sulfates in anhydrite samples from the three different sites; 225, 227, and 228 (Table 1). It may be significant that the average sulfur isotope composition for these anhydrite samples, all of which are upper Miocene age, is $+24.04 \%$; slightly heavier than previously found by Holser and Kaplan (1966). For comparison, the composition of present-day seawater sulfate is $+20 \%$ (Thode et al., 1961).

Water-soluble sulfates from Samples 228-39-1-50 and 228-39-1-110 have isotopic compositions of +9.22 and $+19.18 \%$, respectively. These isotopically lighter sulfates 


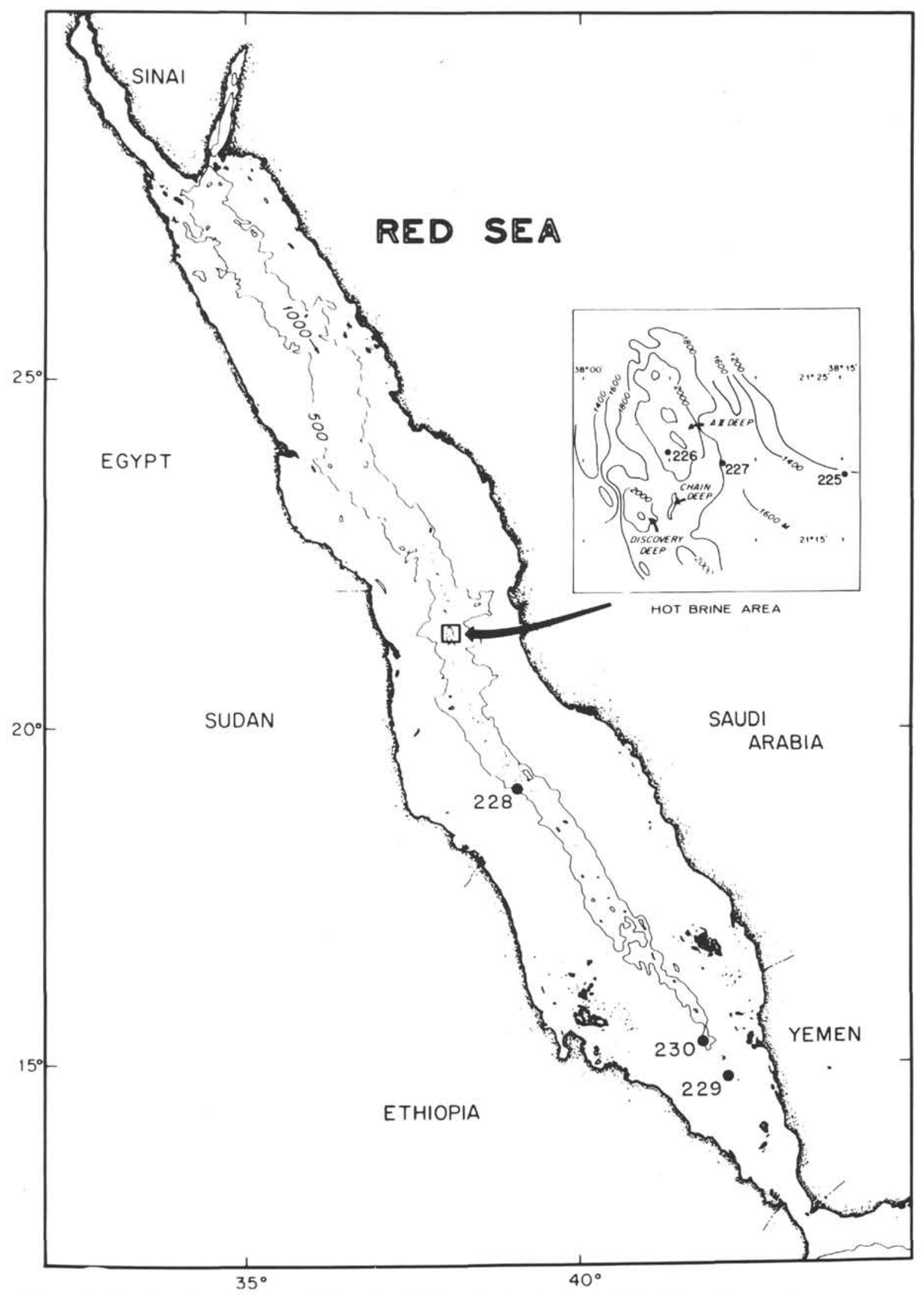

Figure 1. Site locations for Leg 23, Deep Sea Drilling Project in the Red Sea (from Ross et al., 1973). 
TABLE 1

Sulfur Concentration and Isotopes Ratios in Sulfates

\begin{tabular}{|c|c|c|c|c|c|}
\hline Sample & $\begin{array}{l}\text { Depth in } \\
\text { Section } \\
(\mathrm{cm})\end{array}$ & $\begin{array}{l}\text { Sulfate } \\
\text { Sulfur } \\
\text { (wt \%) }\end{array}$ & $\begin{array}{l}\text { Residue } \\
\text { (wt \%) }\end{array}$ & $\delta \mathrm{s}^{34}$ & Description \\
\hline $225-24-1$ & $80-85$ & 22.7 & 0.80 & +24.6 & $\begin{array}{l}\text { White banded } \\
\text { anhydrite }\end{array}$ \\
\hline $225-24-1$ & $135-140$ & 21.9 & 0.84 & $\begin{array}{l}+25.0 \\
+25.2\end{array}$ & $\begin{array}{l}\text { Light gray } \\
\text { anhydrite }\end{array}$ \\
\hline $225-26-1$ & $140-144$ & 22.7 & 0.16 & $\begin{array}{l}+22.5 \\
+23.1\end{array}$ & $\begin{array}{l}\text { White banded } \\
\text { anhydrite }\end{array}$ \\
\hline $225-29-2$ & $10-20$ & 22.3 & 0.35 & +22.8 & $\begin{array}{l}\text { White banded } \\
\text { anhydrite }\end{array}$ \\
\hline $227-37-2$ & - & 22.9 & 2.21 & $\begin{array}{l}+23.3 \\
+23.0\end{array}$ & $\begin{array}{l}\text { Light gray } \\
\text { anhydrite }\end{array}$ \\
\hline $227-44-2$ & $65-70$ & 19.2 & 8.03 & $\begin{array}{l}+26.4 \\
+25.0\end{array}$ & $\begin{array}{l}\text { Gray massive } \\
\text { anhydrite }\end{array}$ \\
\hline $228-35-1$ & - & - & 2.71 & +23.3 & $\begin{array}{l}\text { Gray } \\
\text { anhydrite }\end{array}$ \\
\hline $228-39-1$ & 50 & $0.80^{\mathrm{a}}$ & - & $+9.2^{\mathrm{a}}$ & Green shale \\
\hline $228-39-1$ & 70 & 21.0 & 2.10 & $\begin{array}{l}+23.3 \\
+25.2\end{array}$ & $\begin{array}{l}\text { Dark gray } \\
\text { anhydrite }\end{array}$ \\
\hline $228-39-1$ & 85 & 21.9 & 4.60 & $\begin{array}{l}+23.3 \\
+26.3\end{array}$ & $\begin{array}{l}\text { Dark gray } \\
\text { anhydrite }\end{array}$ \\
\hline 228-39-1 & 90 & 15.7 & - & +23.2 & $\begin{array}{l}\text { Shale with } \\
\text { anhydrite }\end{array}$ \\
\hline $\begin{array}{l}228-39-1 \\
228-39-1\end{array}$ & $\begin{array}{l}110 \\
150\end{array}$ & $\begin{array}{l}1.96^{\mathrm{a}} \\
22.4\end{array}$ & $\overline{10.2}$ & $\begin{array}{l}+19.2^{\mathrm{a}} \\
+23.4 \\
+23.0\end{array}$ & $\begin{array}{l}\text { Shale } \\
\text { Dark gray } \\
\text { anhydrite }\end{array}$ \\
\hline
\end{tabular}

${ }^{\mathrm{a}}$ Cold water-soluble sulfate.

may contain some sulfate from oxidation of metal sulfides during core storage.

The data obtained on sulfides from Site 227 are very negative (Table 2) and are typical of diagenetic pyrite formed by bacterial sulfate reduction in many marine sediments The isotopic composition of sulfides (mainly pyrite and sphalerite) separated from the shales of Core 39, Site 228 are unique, exhibiting a large range of values $(-12.1$ to $+22.3 \%$ ) but displaced to significantly heavier values than those usually characteristic for biogenic sulfides (Kaplan et al., 1963). The average $\delta S^{34}$ ratio of these samples is $+3 \%$.

\section{DISCUSSION}

\section{Sulfur Isotopes in Anhydrite}

Holser and Kaplan (1966), Nielsen (1965), and Thode and Monster (1965) have published data which indicate that the sulfur isotope composition of Tertiary seawater sulfate was close to the $+20 \%$ of present seawater sulfate. In addition to an overall change in the $\delta \mathrm{S}^{34}$ of sulfate in the world ocean, there are two processes which can cause the sulfur isotope ratio of evaporite sulfate to vary from that of contemporaneous seawater. First, isotopic fractionation between the solid phase and seawater may occur. Thode and Monster (1965) experimentally determined that gypsum precipitated from seawater is 1.65 $\%$ heavier than the seawater sulfate.

The other process is a net change in the $\delta \mathrm{S}^{34}$ of the sulfate in a basin which is isolated or partially isolated from open ocean water. In this case, seawater sulfate may
TABLE 2

Sulfur Concentration and Isotope Ratios in Sulfides

\begin{tabular}{|c|c|c|c|c|}
\hline Sample & $\begin{array}{l}\text { Depth } \\
\text { (cm) }\end{array}$ & $\begin{array}{l}\text { Sulfide } \\
\text { Sulfur } \\
\text { (wt \%) }\end{array}$ & $\delta S^{34}$ & Description \\
\hline $227-3-\mathrm{CC}$ & & - & $\begin{array}{l}-35.6 \\
-36.6\end{array}$ & $\begin{array}{l}\text { Bromoform and } \mathrm{HCl} \\
\text { concentrate from shale, } \\
\text { mainly pyrite }\end{array}$ \\
\hline $227-13-\mathrm{CC}$ & & - & $\begin{array}{l}-32.8 \\
-33.4\end{array}$ & $\begin{array}{l}\text { Bromoform and } \mathrm{HCl} \\
\text { concentrate from shale, } \\
\text { pyrite and sphalerite }\end{array}$ \\
\hline $227-44-1$ & $43-47$ & - & -21.9 & $\begin{array}{l}\text { Residue from anhydrite } \\
\text { dissolution in } \mathrm{HCl}\end{array}$ \\
\hline \multirow[t]{2}{*}{$228-39-1$} & $50^{\mathrm{a}}$ & - & $\begin{array}{l}+7.6 \\
+7.3\end{array}$ & $\mathrm{HCl}$ separate from shale \\
\hline & $50^{\mathrm{a}}$ & 5.56 & +12.9 & - \\
\hline $228-39-1$ & 85 & - & +2.4 & $\begin{array}{l}\text { Bromoform and } \mathrm{HCl} \\
\text { separate from shale }\end{array}$ \\
\hline \multirow[t]{2}{*}{$228-39-1$} & $90^{\mathrm{a}}$ & - & -9.1 & $\begin{array}{l}\text { Bromoform and } \mathrm{HCl} \\
\text { separate from shale }\end{array}$ \\
\hline & $90^{\mathrm{a}}$ & 0.33 & -2.3 & $\mathrm{HCl}$ separate \\
\hline $228-39-1$ & 110 & 1.21 & -12.1 & $\mathrm{HCl}$ separate from shale \\
\hline $228-39-1$ & 130 & - & $\begin{array}{l}+22.3 \\
+22.1 \\
\end{array}$ & $\begin{array}{l}\text { Bromoform and } \mathrm{HCl} \\
\text { separate from shale }\end{array}$ \\
\hline
\end{tabular}

${ }^{\mathrm{a}}$ Separate runs on splits of unhomogenized samples.

become isotopically heavy or light, depending on the relative intensity of two processes: (1) the fresh water inflow brings isotopically light sulfate into the evaporating basin and (2) under reducing conditions, biogenic sulfate reduction causes seawater sulfate to become isotopically heavy. It is apparent that the effects of both of these processes become more important as the volume of water in a basin decreases and a significant portion of gypsum precipitates out by evaporation.

The average $\delta \mathrm{S}^{34}$ of the upper Miocene anhydrite determined from the Red Sea is $+24 \%$ and the minimum $+22.5 \%$. These data suggest that sulfate reduction may have occurred in the environment of deposition at different times in the history of the basin.

\section{$\mathrm{S}^{34} / \mathrm{S}^{32}$ in Metal Sulfides}

The sulfides at all three sites were mainly pyrite, although sphalerite was identified by X-ray diffraction at Site 227, Core 13. The sulfides isolated from cores at Site 227 yielded isotopic values typical of normal marine sulfides isolated from continental shelf environments (Kaplan et al., 1963). This sulfide must have resulted from biological sulfate reduction in a large reservoir of sulfate, either in the lower water body or at the sediment-water interface.

However, the $\delta S^{34}$ results from Site 228 are very heterogeneous and indicate that discontinuous processes must have been responsible for the sulfide deposition. The range in $\delta \mathrm{S}^{34}$ of the fraction analyzed as sulfide is -12.1 $\%$ to $+22.2 \%$. The fraction labeled as sulfide was the residue left after water and hydrochloric acid leaching. It is conceivable that some insoluble sulfate (such as barite) remained in the residue, but it was not recognized either by microscopy or by X-ray diffraction. Pyrite appeared to be the dominant component of the residue. Framboidal pyrite 
as well as individual pyritohedron crystals were observed in the residue of Sample 228-39-1-130.

Assuming the $\delta \mathrm{S}^{34}$ values measured do in fact represent sulfides, two possible mechanisms can be assigned for the origin. One assumes an authigenic origin with the sulfide formed in place by biological sulfate reduction. By this mechanism, organic-rich shales are degraded by sulfate reduction during burial. A steady-state condition is set up in which anhydrite dissolves while sulfate from the pore water is utilized. If all the sulfate in solution is used, the ultimate value for $\delta \mathrm{S}^{34}$ of the sulfide should approach +24 $\%$, the average value of these Miocene evaporites. A range of values from typical marine to $+24 \%$ could therefore result, depending on how much sulfate is reduced. In this event any residual pore water sulfate should be isotopically heavy. However, pore water from these particular core sections was not available for sulfur isotopic analysis. Sulfate removed from the solids by water washing (which may represent evaporated interstitial water) was, in fact, isotopically lighter than present-day seawater sulfate, possibly due to pyrite oxidation during sample crushing or storage.

An alternate explanation is that the sulfides in the sediments represent a mixture of two (or more) sources. One is isotopically light authigenic sulfide formed within the sediment column and the other is isotopically heavy sulfur introduced by hydrothermal solutions. This mechanism, however, would require very heavy (unreasonably so) hydrothermally introduced sulfur.

The details of the process which forms these unique sulfides and possible relationships to the base metal sulfides of the Atlantis II Deep must be left for further investigation. Particularly significant problems are the source of zinc, sulfur isotopic composition of carefully separated mineral phases and pore water sulfate, and mineralogical evidence for secondary processes.

\section{ACKNOWLEDGMENTS}

We wish to thank Dave Winter for assistance in the sulfur isotope analysis and also Marty Goldhaber and Dr. T. L. Ku for useful ideas and suggestions.

This study was supported by American Chemical Society Grant PRF 5107-AC2 and National Science Foundation Grant GA-23495.

\section{REFERENCES}

Ault, W. U. and Kulp, J. L., 1960. Sulfur isotopes and ore deposits: Econ. Geol., v. 55, p. 73-100.

Bischoff, J. L., 1969. Red Sea geothermal brine deposits: Their mineralogy, chemistry, and genesis. In Hot brines and recent heavy metal deposits in the Red Sea: Degens, E. T. and Ross, D. A. (Eds.), New York (SpringerVerlag), p. 368-401.

Hackett, J. P. and Bischoff, J. L., 1973. New data on the stratigraphy, extent, and geologic history of the Red Sea geothermal deposits: Econ. Geol., v. 68, p. 553-564.

Hartmann, M. and Nielson, H., 1966. Sulfur isotopes in the hot brine and sediment of Atlantis II Deep (Red Sea): Mar. Geol., v. 4, p. 305-306.

Holser, W. T. and Kaplan, I. R., 1966. Isotope geochemistry of sedimentary sulfates: Chem. Geol., v. 1, p. 93-135.

Jensen, M. L., 1967. Sulfur isotopes and mineral genesis. In Geochemistry of hydrothermal ore deposits; Barnes, H. L. (Ed.), New York (Holt, Rinehart, and Winston, Inc.), p. 143-165.

Kajiwara, Y., 1971. Sulfur isotope study of Kuroko-ores of Shakani No. 1 deposits, Akita Prefecture, Japan: Geochem. J. v. 4, p. 157-181.

Kaplan, I. R., Emery, K. O., and Rittenberg, S. C., 1963. The distribution and isotopic abundance of sulfur in recent marine sediments off southern California: Geochem. Cosmochim. Acta.,v. 27, p. 297-337.

Kaplan, I. R., Sweeney, R. E., and Nissenbaum, A., 1969. Sulfur isotope studies of Red Sea geothermal brines and sediments. In Hot brines and recent heavy metal deposits in the Red Sea: Degens, E. T. and Ross, D. A. (Eds.), New York (Springer-Verlag), p. 474-498.

Nielsen, H., 1965. Schwefelisotopes im marinen Kreislauf and das ${ }^{34} \mathrm{~S}$ der fruheren Meere: Geol. Rundschau, v. 55 , p. $160-172$.

Ross, D. A., Whitmarsh, R. B., Ali, S. A., Boudreaux, J. E., Coleman, R., Fleisher, R. L., Girdler, R., Manheim, F., Matter, A., Nigrini, C., Stoffers, P., and Supko, P., 1973. Red Sea drillings: Science, v. 179, p. 377-380.

Sangster, D. F., 1968. Relative sulfur isotope abundances of ancient seas and strata-bound sulfide deposits: Geol. Soc. Canada Proc., v. 19, p. 79-91.

Stanton, R. L., 1972. Ore petrology: New York (McGraw-Hill).

Thode, H. G. and Monster, J., 1965. Sulfur-isotope geochemistry of petroleum, evaporites, and ancient seas. In Fluids in subsurface environments: A.A.P.G. Memoir 4, p. 367-377.

Thode, H. G., Monster, J.. and Dumford, H. B., 1961. Sulfur isotope geochemistry: Geochim. Cosmochim. Acta, v. 25 , p. 159-174. 